\title{
Dvě knihy Libora Martinka
}

\author{
Ivo Pospíšil (Brno)
}

Libor Martinek: Henryk Jasiczek. Opava: Vydavatelství a nakladatelství Literature \& Sciences, 2016. 270 s. ISBN 978-80-904126-6-8.

Libor Martinek: Lašsko-evropský básník Óndra Łysohorsky. Wrocław: Wrocławskie Wydawnictwo Oświatowe, 2016. 221 s. ISBN 978-83-7977-221-6.

Svou monografii o polském básníkovi žijícím na území bývalého Československa Henryku Jasiczkovi (1919-1976) dal L. Martinek k posouzení ideologickým koryfejům české a polské literární vědy: tomu také odpovídá poněkud zvláštní výběr použité literatury, kde vedle sebe stojí knihy a studie relevantní a současně ideologické „záštity“, na jaké jsme byli zvyklí vlastně pořád za všech režimů. Ale jinak je to kniha inspirativní, s teoretickým přesahem, na jaký jsme u Martinka zvyklí. Nemám rád recenze osobně zaujaté negativně nebo pozitivně a ani pajánovité posudky, spíše kritický př́istup. Takoví recenzenti však nejsou oblíbení, protože nestojí v žádném ideovém táboře, nemají rádi sevřené šiky, nevyjadřují to, co se od nich chce, zároveň nejsou oblíbeni ani autory, kteří by spíše čekali oslavu: mnohem důležitější je ono kritické posouzení, jež autor ocení většinou až mnohem později, pokud vůbec. Recenzent by měl hledat nejen momenty slabší, ale hlavně to, co je zde nosné, transcendující. Básník Jasiczek, který se stal oporou socialistické literatury, prožil určitou proměnu na konci šedesátých let minulého století, nakolik hlubokou, zůstává otázkou, na niž autor odpovídá jen zčásti. V každém případě jde o klíčovou postavu polské literatury v českém prostředí, o autora kvalitního, poctivého. Martinkova monografie je komplexní: autor invenčně mapuje celé autorovo dílo, tedy nejen básnické: najdeme tu jeho prózu, paměti, tvorbu pro děti, v druhé části i malou antologii Jasiczkovy poezie polsky a také trochu česky, důležitá je i dokumentární fotografická př́iloha. Martinek se dívá na Jasiczka moderně, neváhá pojednat o sakrálním a profánním (vzpomínám si na to, jak se o tento módní přístup pokoušel můj přítel, zvěčnělý Blahoslav Dokoupil, 19522008; řekl bych, že každý by měl psát podle své letory a nátury a nejsem si jist, jestli toto pojetí u Jasiczka něco podstatného přineslo). Naopak velmi funkční je analýza vztahu literatury a hudby, korespondence a pojednání o krizi básníkovy identity, o jeho vztahu k nacionalistickým platformám a vůbec $\mathrm{k}$ pozici polské menšinové literatury v českém prostředí a také $\mathrm{k}$ pozici této literatury v polské literatuře jako takové. Ty vztahové věci jsou vždy citlivé a delikátní. $\mathrm{V}$ tomto smyslu zůstává Martinek pochopitelně „vyváženým“, tedy nezastírá, ale současně razantně neřeší, spíše nechává hovořit fakta, události a postoje, je otázka, zda všechny. To, co je na Martinkově knize mimořádně cenné a důležité, je implicitní i explicitní teoretický a metodologický rozměr, tedy to, co kniha přináší obecně k studiu tohoto typu literatury. Kromě toho je tu bohemisticko-polonistický aspekt, vztahově komparativní, ale i posun k zkoumání kontextů české literatury, jak se to objevilo a objevuje třeba v případě německy psané literatury v Zemích Koruny české, nebo u mad’arské nebo ukrajinsko-rusínské literatury na Slovensku. Martinek to ostatně potvrdil i svými předchozími knihami o literatuře Těšínska, o nichž jsem také psal (Uchopeni problému: současná polská literatura českého Těšnska. Libor Martinek: Polská literatura českého Těšínska po roce 1945. Opava: Ústav bohemistiky a knihovnictví Filozoficko-př́rodovědecké fakulty Slezské univerzity v Opavě, 2004. Slavica litteraria, X 8, 2005, s. 219-220; Podnětná kniha o literature Těšinska: vykričniky a otazniky. Libor Martinek: Identita 
v literatuře Těšínska. Kielce - Opava: Vydalo naklad. STON2 ve spolupráci s Nakladatelstvím a vydavatelstvím Literature \& Sciences, 2015. Opera Slavica, 2016, č. 3, s. 79-82). Knihy L. Martinka mají nejen teoretický, ale i praktický význam pro spisovatelskou situaci v zemích, kde se píše různými jazyky a kde se musejí zkoumat souvislosti mezi různými národními literaturami: to platí jak pro Čechy, tak pro Slováky. Zvláštní postavení mají v knize pasáže o různých sférách Jasiczkovy opravdu bohaté činnosti: byl publicistou, psal rozhlasové pořady, memoáry, které jsou přirozeně do značné míry důležitým pramenem k jeho životu a dílu. Prožíval ovšem i krizi identity, ale pro mě je nejpozoruhodnějš́i kapitola o jeho styku se zásvětím - to je u takových složitých osobností dost příznačné. Za klíčovou pro českou slavistiku a bohemistiku v širokém slova smyslu považuji kapitolu o recepci Jasiczka v českém prostředí (s. 162-179). Jde o důkladnou, materiálově snad vyčerpávající studii, bez níž by výklad Jasiczkova díla nebyl úplný; proto ji nutno doporučit našim bohemistům, zejména těm, kteří si dobře uvědomují, že česká literatura nebyla nikdy uzavřenou monádou, že se vždy vyvíjela v širokém kontextu jiných literatur, nejen německé, ale právě polské, ukrajinsko-rusínské, mad’arské. Martinek vyzvedává zejména zatím de facto poslední fázi recepce Jasiczka na stránkách různých podob časopisu Alternativa, píše mimo jiné o práci zvěčnělého Drahomíra Šajtara - a co zvláště oceňuji je jeho př́stup sine ira et studio, když nezaujatě hodnotí výstupy kritika a překladatele, který v posledních třech desetiletích rozhodně nepatřil u nás hlavně z ideologického hlediska k oceňovaným (Oldřich Rafaj, s. 174-177). Autor se možná měl ještě více věnovat pozici takových autorů v prostředí jejich mateřské literatury - to bývá docela složité a jistě by to prospělo polské polonistice. Ke každé kapitole by bylo jistě možno vznést podstatnější i méně podstatné připomínky (nebylo by jich zase tak mnoho) obecnější i konkrétnější povahy, ale ty poslední by mohl učinit jen někdo, kdo má alespoň takové faktografické znalosti předmětu jako autor monografie a to jsou nebo spíse byli právě ti, na něž se často kriticky odvolává. Výbor z básní Henryka Jasiczka polský i český, jímž se kniha uzavírá, je udělán kvalitně, s rozmyslem a stř́ílivostí, stejně jako fotopříloha.

Druhá kniha je z hlediska nejednoznačnosti názoru na Martinkův předmět - lašského básníka, barda a lingvistu Óndru Łysohorského (1905-1989; příznačné je nejen to, kde se narodil - Frýdek, ale hlavně, kde zemřel - Bratislava) - ještě zajímavější a podnětnější také proto, že se tu Martinek musel kriticky vyrovnat s kvalitními pracemi svých předchůdců, k nimž patřil zejména letitý emigré, zvěčnělý Jiří Marvan (1936-2016), ale i další (Pavel Gan), kteří připravili výbory z jeho tvorby (mj. Lašsko poezyja,1939-1977, vyd. Kolín nad Rýnem - Vídeň 1988; Lachische Poesie, 1989 - jde o německé překlady), ale i s kreativitou překladatelů. Sám Óndra Łysohorsky je vynikající postavou lašského obrození, lingvistou par excellence, i když mnozí mají k němu podstatné výhrady, originální básník a především tvưrce jazykové osobitosti a identity lašského jazyka stojícího na hraně němčiny, polštiny a češtiny; proto se jeho snahy o kodifikaci lašštiny v podstatě nikde nesetkaly s kladným přijetím - ani v de facto centralisticky budovaném meziválečném Československu, ani v SSSR, kam se básník uchýlil po okupaci zbytku českých zemí a kde neváhal napsat na jaře 1944 dopis samotnému Josifu Vissarionoviči Stalinovi - ze to samozřejmě nebyl nijak chválen (dopis se nachází ve svazku v autorem jazykově upraveném českém překladu). Óndra Łysohorsky se narodil jako Erwin Goy (Ervin Goj). Pohyboval se, do škol chodil a studoval ve vícejazyčném prostředí Slezska a severní Moravy, studoval na německé univerzitě v Praze (později se stal vlastně německým básníkem), vystudoval slavistiku, napsal doktorskou disertaci o R. M. Rilkovi, svoje znalosti prohluboval na letních školách a na cestách v Německu, Francii, Itálii i jinde, velmi se zajímal o SSSR, kde ve válečných letech až do roku 1946 žil a pracoval. Jeho snahy národně obrozovací byly jistě rozporné a v mnohém utopické, ale jeho tvorba i národní úsilí ukázalo v plné nahotě prázdnotu centralistické koncepce vícenárodních států a také její škodlivost pro budoucnost národů střední Evropy i obecně. $\mathrm{V}$ tomto smyslu i všeobecně projevovaná skepse 
k Óndrovi Łysohorskému postupně bledne také tváří v tvář novým výzvám, jimž současná integrující se i dezintegrující se Evropa dnes čelí. V tomto smyslu označení Óndry Łysohorského jako lašsko-evropského básníka převzaté odjinud má svůj význam a není jen módní etiketou. Práce L. Martinka je sice monografická, ale v podstatě je založena na srovnávací koncepci vnitřní i vnější, i když právě na tu autor deklarativně jako by rezignuje, ale myslím, že ne zcela. O tom svědčí partie o překládání jeho díla v Rusku, o vztahu k Bezručovi apod. Jde také o práci v jistém smyslu poetologickou, nebot autor sleduje i autonomní vývoj poetiky, a to zejména Łysohorského poezie. Jeho práce je komparatistická jako studium přijetí básníka v různých obdobích a prostředích, nese také stopy recepční estetiky, což je možná ještě podnětnější. To, co jsme napsali o charakteru hodnocení recepce Óndry Łysohorského, můžeme zopakovat i zde, což se týká zejména posledního období po roce 1989. Ukazuje se, že Óndra Łysohorsky nepůsobil ani tak tvarem své poezie jako celou svou osobností a jejím cha- rizmatem, nebot' ohlasy jeho osobnosti a díla najdeme u řady českých básníků a nejen jich: zájem o Łysohorského v Polsku, Německu, Rusku i jinde je příznačný. Příznačná je v tom i báseň Lašská ř rec Jiř́iho Taufra (1911-1986) z roku 1937 věnovaná právě Óndrovi Łysohorskému: „Horlici jako plamen jenž o svém žáru nevi / trpká jak černá hlína jež lesky kyzů hrá / těžká a plná jako zrno když ve žnich odlétaji plevy / sladká jak réva ach réva / jež na severu nikdy nedozrá..." (uvedena jako motto kapitoly na s. 16). Zájem překladatelů dokládají mj. Zdenka Bergrová (1923-2008) a Ewald Osers (1917 Praha - 2011 Reading). Dílo Óndry Łysohorského kompetentně interpretované L. Martinkem, vzbuzuje řadu otázek a vede $\mathrm{k}$ moha přesahům, k nimž patří vývoj poezie 20. století, problém malých národů a jazyků, centra a periferie, socialismu, kapitalismu, liberalismu a konzervatismu, jak se projevovaly a dodnes projevují v společenském životě evropské a euro-americké civilizace $i$ jinde.

\section{prof. PhDr. Ivo Pospíšil, DrSc.}

Ústav slavistiky

Filozofická fakulta, Masarykova univerzita

Arna Nováka 1, 602 00, Brno, Česká republika

ivo.pospisil@phil.muni.cz 